\section{Fluoride Varnishes against Dental Erosion Caused by SoftDrink Combined with Pediatric Liquid Medicine}

\author{
Adilis Kalina Alexandria ${ }^{1}$ Ana Maria Gondim Valença², Lúcio Mendes Cabral ${ }^{3}$, \\ Lucianne Cople Maia ${ }^{1}$
}

'Department of Pediatric Dentistry and Orthodontics, Dental School, UFRJ - Universidade Federal do Rio de Janeiro, Rio de Janeiro, RJ, Brazil ${ }^{2}$ Department of Clinical and Social Dentistry, Dental School, UFPB - Universidade Federal da Paraiba, João Pessoa, PB, Brazil ${ }^{3}$ School of Pharmacy, UFRJ Universidade Federal do Rio de Janeiro, Rio de Janeiro, RJ, Brazil

Correspondence: Lucianne Cople Maia, Cidade Universitária - CCS, 21941-971 Rio de Janeiro, RJ, Brasil. Tel: +55-21-3938-2101. e-mail: rorefa@terra.com.br

Key Words: dental enamel, oral administration, pharmaceutical preparations, acidity, topography.

\section{Introduction}

Dental erosion is the dissolution of teeth minerals by acids with no bacteria involvement. The chemical wear results in a roughened structure and the loss of tissue that may appear like a visible defect on dental surface $(1,2)$. Dental erosion has a high prevalence, mainly among children and adolescents (3) and it has extrinsic or intrinsic causes (4).

The extrinsic causes include consumption of acidic foods or drinks and use of acidic medicines or acidic hygiene products (5). Liquid medicines are widely used for children because the facility of ingestion $(5,6)$. However, some of inactive acidic components have low $\mathrm{pH}(5,7)$ and because of the high frequency of medication intake, bedtime consumption, high viscosity and reduction of the salivary flow, it may also be associated with alterations on surface morphology of dental enamel (5).

Some preventive actions have been suggested to avoid the start of the erosive process, like using professional topical fluorides $(8,9)$. Furthermore, the addition of new remineralizing compounds to fluoride varnishes may be an alternative to obtain better effects against erosive wear.

Casein Phosphopeptide-Amorphous Calcium Phosphate Nanocomplexes (CPP-ACP) is the Recaldent ${ }^{\mathrm{TM}}$ technology based on stabilization of amorphous calcium phosphate (ACP) by casein phosphopeptides (CPP). It has been reported that the CPP-ACP nanocomplexes provide high concentration of calcium and phosphate ions. CPP-ACP compound can interact with fluoride ions to produce an ACFP phase and provide better benefits to teeth $(10,11)$. To the best of the authors' knowledge, the influence of CPP-ACP/NaF varnish on erosion prevention has not yet been investigated. Therefore, the purpose of this in vitro study was to evaluate the effect of CPP-ACP/NaF varnish compared with $\mathrm{NaF}$ varnish to provide protection against the erosion produced by soft drink combined or not with pediatric liquid medicine.

\section{Material and Methods}

\section{Specimen Preparation}

Enamel specimens $(4 \times 4 \times 2 \mathrm{~mm})$ were prepared from the labial surfaces of bovine incisors crowns. The specimens were cut using an ISOMET low-speed saw (Buehler Ltd, Lake Bluff, IL, USA) with 2 diamond discs (Extec Corp, Enfield, CT, USA) with a 4-mm spacer. The specimen's surface was polished using water-cooled silicon carbide paper 600 and 1200 (Extec Corp.). After each polishing 
phase, the specimens were cleaned in an ultrasound device with distilled and deionized (DD) water (Milli- ${ }^{\circledR}{ }^{\circledR}$, Merck Millipore Corporation, Darmstadt, Germany) for 5 min. The specimens were checked regarding the presence of white spots and cracks using a microscope (40x).

Baseline surface roughness ( $\mathrm{Sa}$ ) of the enamel surface was measured $(\mathrm{Sa}=1.82 \pm 0.18 \mu \mathrm{m})$, using a 3D noncontact chromatic confocal optical profilometry (Nanovea PS50 Optical, NANOVEA Inc., Irvine, CA, USA). An area of $1 \times 1$ $\mathrm{mm}$ was delimited in the center of each sample. Three scans for each area $(200 \times 200 \mu \mathrm{m})$ were acquired and the average was used to determine the Sa.

Prior to the experiment, a nail varnish was applied in the right half of the specimen's surface to maintain a sound reference surface (unexposed area, self-control per specimen), the other half of the surface (left side) was not covered, representing the exposed area. The specimens were maintained in 100\% humidity until the beginning of the experiment.

\section{Treatment and Erosive Cycling}

The fluoride varnishes utilized in this study were: (1) $\mathrm{NaF}$ varnish ( $5 \% \mathrm{NaF}$, Duraphat ${ }^{\circledR}$, Colgate Oral Pharmaceuticals, New York, NY, USA) and (2) CPP-ACP/NaF varnish (2\% CPPACP and 5\% NaF, MI Varnish ${ }^{\mathrm{TM}}$, GC America, Alsip, IL, USA).

Sixty enamel specimens were randomly allocated to 6 groups $(n=10)$ according to treatment and type of erosion challenge: $\mathrm{G} 1=\mathrm{NaF}$ varnish + soft drink erosion; $\mathrm{G} 2=\mathrm{CPP}-$ $\mathrm{ACP} / \mathrm{NaF}$ varnish + soft drink erosion; $\mathrm{G} 3=\mathrm{DD}$ water + soft drink erosion (negative control for soft drink erosion); $\mathrm{G} 4=$ $\mathrm{NaF}$ varnish + pediatric liquid medicines/soft drink erosion; $\mathrm{G} 5=\mathrm{CPP}-\mathrm{ACP} / \mathrm{NaF}$ varnish + pediatric liquid medicine/ soft drink erosion and G6= DD water + pediatric liquid medicine/soft drink erosion (negative control for pediatric liquid medicines + soft drink erosion).

The sample size of 10 specimens was based on a 0.8

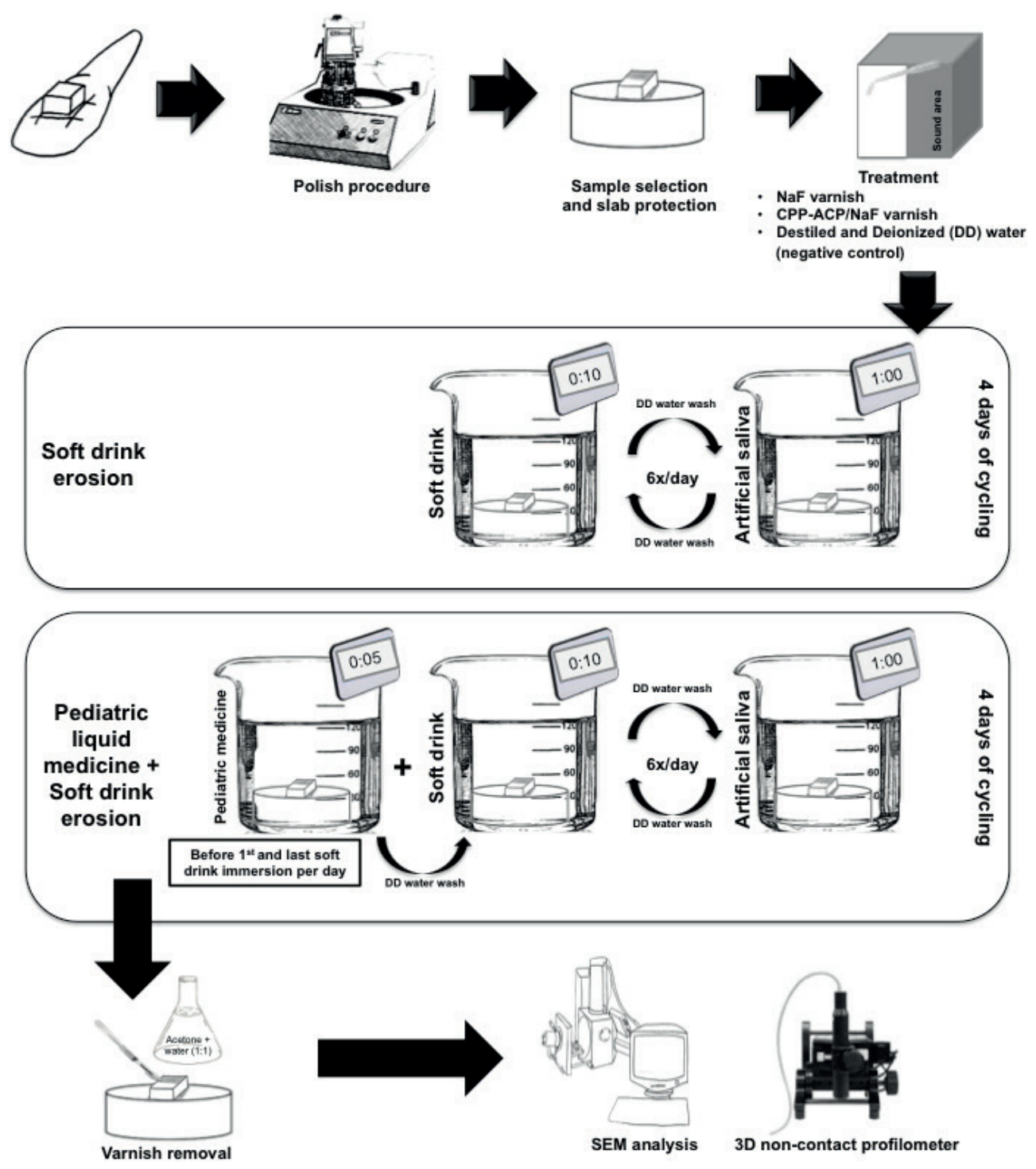


power to detect a significant difference of 50\% in tooth structure loss (TSL) in each varnish groups compared to negative control, using a one-sided test considering a 5\% error level and 20\% b-error level (BioEstat 5.3, Instituto de Desenvolvimento Sustentável Mamirauá, Tefé, AM, Brazil).

In groups $\mathrm{G} 1, \mathrm{G} 2$ and $\mathrm{G} 3$ soft drink erosion (SDE) were performed with Coca-Cola ${ }^{\circledR}$ (Coca-Cola ${ }^{\circledR}$ Company, Porto Real, RJ, Brazil) and in G4, G5 and G6, with pediatric liquid medicine plus soft drink erosion (PLM/SDE) were performed immersing the specimens in Claritin ${ }^{\circledR}$ (Schering-Plough, Kenilworth, NJ, USA) and in Coca-Cola ${ }^{\circledR}$ (Fig. 1).

The varnishes in G1, G2, G4 and G5 groups were applied once at the beginning of the experiment in a thin layer on specimen surface, using a microbrush. After $6 \mathrm{~h}$ of immersion in artificial saliva $(1.5 \mathrm{mmol} / \mathrm{L} \mathrm{Ca}, 0.9 \mathrm{mmol} / \mathrm{L} \mathrm{P}$, $150 \mathrm{mmol} / \mathrm{L} \mathrm{KCl}, 0.05 \mathrm{mg} \mathrm{F} / \mathrm{mL}$ in $0.1 \mathrm{~mol} / \mathrm{L}$ Tris buffer, $\mathrm{pH}$ $7.0,25 \mathrm{~mL} / \mathrm{sample})(12,13)$, the layer of varnish was removed using a scalpel blade and acetone with water (1:1) (13$15)$, the total removal was checked microscopically $(\square 40)$.

In order to simulate the clinical situation, all samples were subjected to erosive cycles for 4 days. All groups were submitted to 6 SDE per day for 10 min each (16), using freshly opened bottles of Coca-Cola ${ }^{\circledR} \mathrm{pH} 2.58,15$ $\mathrm{mL} /$ specimen. Furthermore, the samples of $\mathrm{G} 4, \mathrm{G} 5$ and $\mathrm{G} 6$ were also immersed 2x/day (before the first and last soft drink immersion) for $5 \mathrm{~min}$ in a pediatric liquid medicine (Claritin ${ }^{\circledR}$ ) (17), pH 2.12, $15 \mathrm{~mL} / \mathrm{specimen}$. Between each SDE, the samples of all groups were immersed in artificial saliva. After each erosive period, samples were rinsed in DD water. The experiment was carried out at $37^{\circ} \mathrm{C}$ (Fig. 1).

\section{Profilometric Analysis}

After 4 days of experiment, the layer of acid-resistant nail varnish was removed using acetone with water (1:1) (13-15), allowing the comparison between the unexposed and exposed areas.

A chromatic confocal sensor with a white light axial of 3D non-contact optical profilometer scanned an area of $1 \times 1 \mathrm{~mm}$ on each specimen (velocity of $2 \mu \mathrm{m} / \mathrm{s}$ ) and generated one image for each sample. The images were analyzed by Nanovea Professional 3D software (Nanovea PS50 Optical, NANOVEA Inc.) to determine tooth structure loss (TSL) and surface roughness (Sa), according to previous studies $(13,17)$.

Tooth structure loss $(\mu \mathrm{m})$ was evaluated at the center of each specimen; three 1-mm-long linear measurements were made involving the unexposed and exposed area to calculate the difference in height between the unexposed and exposed enamel surface in each specimen. All measurements were done in triplicate, and the average was used to represent the final result of the specimen's surface profile.
To determine Sa, three scans $(200 \mu m \times 200 \mu m)$ were acquired in each area (unexposed and exposed areas) on the enamel specimen. The average of these three measurements in each area was used to determine Sa1 (surface roughness in unexposed area) and Sa2 (surface roughness in the exposed area), the Sa value for all groups was calculated as the difference between Sa 1 and Sa2 by using the following formula: Sa $=$ Sa $1-$ Sa2 .

\section{D Profilometry Images and Scanning Electron Microscopy (SEM)}

One 3D topographical image was chosen to represent the results of each group. Two SEM micrographs of each group were also obtained.

3D topographical images were constructed from scanned area $(1 \times 1 \mathrm{~mm})$ by Nanovea Professional 3D software, all images were standardized in height parameter. SEM analysis was performed in scanning electron microscope (6460LV, JEOL, Akishima, Tokyo, Japan). Three enamel specimens of each group were randomly selected, covered with a $30-\mu \mathrm{m}$ gold layer and fixed on stubs with double-faced carbon tape. The topography of enamel specimens was analyzed by backscattered electrons at $20 \mathrm{kV}$ in low vacuum mode $(45 \mathrm{~Pa})$. The SEM micrographs at $\times 500$ magnification were used to observe the interface between areas (unexposed and exposed) and those at $\times 2000$ magnification were used to have a more detailed view of the surface alterations. The schematic design of the experimental protocol is shown in Figure 1.

\section{Statistical Analysis}

The normal distribution of data was checked for all of the tested variables, using the Shapiro Wilks test. Differences in TSL and Sa among treatments were tested using one-way ANOVA followed by Tukey test. SPSS software version 22.0 (IBM, New York, NY, USA) was used for statistical analysis. The significance level was set at $5 \%$.

\section{Results}

Table 1 summarizes the 3D non-contact profilometry results for TSL and Sa values after SDE challenge. The specimens of $\mathrm{G} 1$ and $\mathrm{G} 2$ did not differ between each other $(p=0.203)$ and only $\mathrm{G} 2$ differed statistically from $\mathrm{G} 3$ $(p=0.008)$ showing lower average value for TSL $(26.68 \pm 3.93$ $\mu \mathrm{m})$. About alterations in surface roughness, G1, G2 and G3 did not differ among them $(p=1.00)$.

Evaluating the PLM/SDE challenge results, regarding TSL and Sa, both $\mathrm{G} 4$ and $\mathrm{G} 5$ did not differ between them $(p=1.00)$, but differed statistically from $G 6(p=0.0001)$. These results are in Table 2.

The differences in the magnitude of treatment surface effect can be seen on the 3D topographical (Fig. 2) and 
SEM images (Figs. 3 and 4). Figure 2 shows the topographic characteristics of the surface enamel at the end of the experiment. The greater the areas in blue, the greater the tooth structure loss. In contrast, the greater the areas in red in the images, the smaller the tooth structure loss.

All groups had tooth structure loss and a significant increase in surface roughness. However, G3 and G6 groups showed a greater difference between unexposed and exposed areas. This issue became evident by the color. Color variation was less evident in the other groups and when $\mathrm{G} 1$ and $\mathrm{G} 2$ were compared with $\mathrm{G} 3$ as well as when $\mathrm{G} 4$ and $\mathrm{G} 5$ were compared with $\mathrm{G} 6$.

The same features were observed in the images obtained by SEM analysis (Figs. 3 and 4), in which $\mathrm{G} 3$ and $\mathrm{G} 6$ presented the worst alterations in enamel topography with great depressions/craters and exposure of enamel prisms.

\section{Discussion}

The irreversible loss of tooth tissue by exogenous or endogenous acids is characteristic of dental erosion
$(1,2)$. This process results in a progressive softening of the superficial and near-surface layer of enamel $(4,8)$.

Some pediatric liquid medicines have certain acidic components that offer chemical stability, tonicity or improve their flavor (7), which can contribute to increase their erosive potential. Many of these pediatric medicines are usually used in treatments for long periods and are consumed daily (18). In addition to this fact, many children also use daily carbonated soft drinks that have low endogenous $\mathrm{pH}$ and may also contribute to dental erosion. Therefore, it is important to evaluate products that can reduce the erosion caused by soft drinks and by soft drinks consumed together with pediatric medicines to reproduce as close as possible the real situation.

In a previous study (17), our research group evaluated the influence of pediatric liquid oral medicines on enamel topography, and concluded that the majority of the studied pediatric medicines have low $\mathrm{pH}$, mainly at room temperature; and Claritin $^{\circledR}$ demonstrated in vitro the capacity to create significant gaps between the unexposed
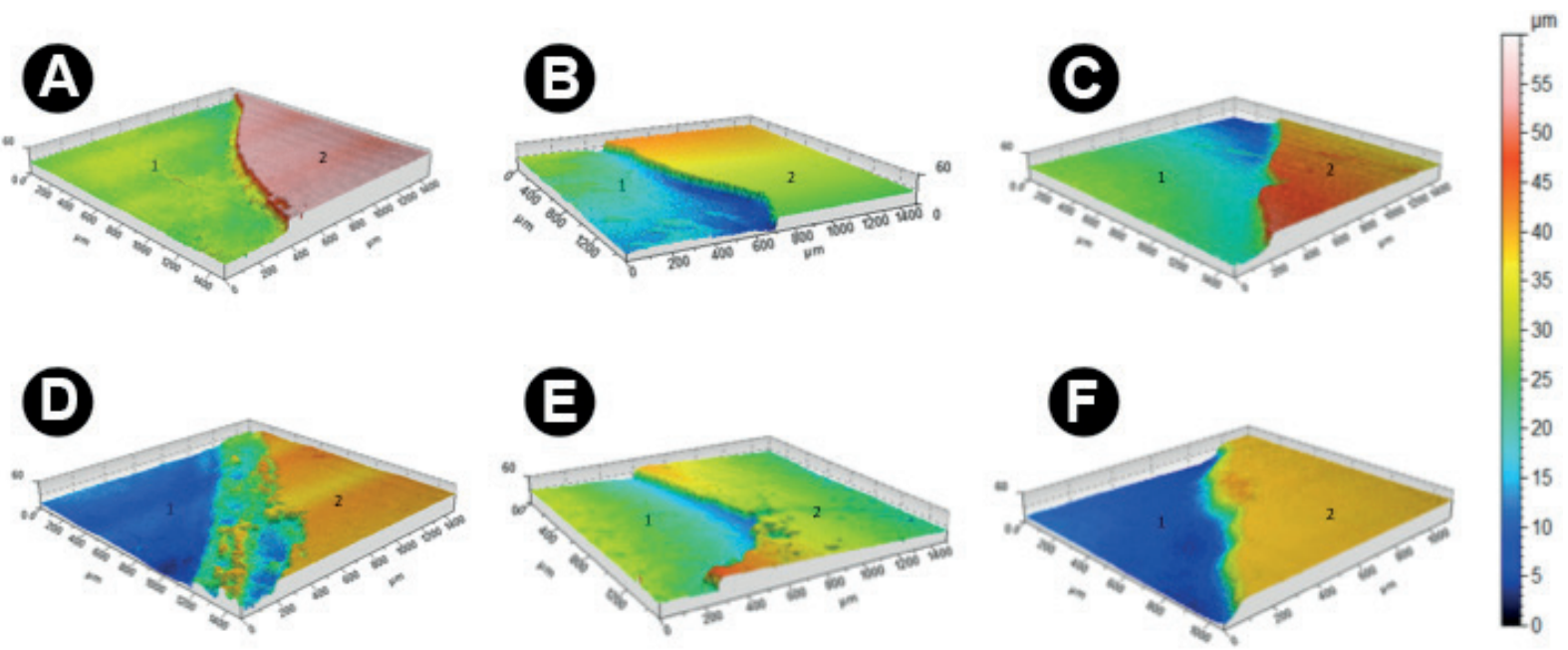

Figure 2. 3D profilometry images of enamel surface samples after treatment and erosion challenges for each group. A-C images = soft drink erosion challenge, D-F images = pediatric liquid medicine + soft drink erosion challenge. (A) and (D) G1 and G4= NaF varnish, (B) and (E) G2 and G5= $\mathrm{CPP}-\mathrm{ACP} / \mathrm{NaF}$ varnish, (C) and (F) G3 and G6= DD water (negative control). $1=$ exposed area (after erosion), $2=$ the unexposed area (sound enamel).

Table 1. Mean of tooth structure loss (TSL) and surface roughness (Sa) $( \pm \mathrm{SD})$ of enamel specimen groups after soft drink erosion challenge

\begin{tabular}{lll}
\hline \multirow{2}{*}{ Groups } & \multicolumn{2}{l}{ 3D non-contact profilometry results } \\
\cline { 2 - 3 } & \multicolumn{1}{l}{ TSL } & Sa \\
\hline G1 (NaF varnish) & $30.01 \pm 4.87 \mathrm{a}, \mathrm{b}$ & $0.73 \pm 0.62 \mathrm{a}$ \\
G2 (CPP-ACP varnish) & $26.68 \pm 3.93 \mathrm{a}$ & $0.64 \pm 0.43 \mathrm{a}$ \\
G3 (DD water) & $32.85 \pm 3.10 \mathrm{~b}$ & $0.86 \pm 0.53 \mathrm{a}$ \\
\hline
\end{tabular}

Means followed by distinct letters are statistically different $(\mathrm{p}<0.05)$.
Table 2. Mean of tooth structure loss (TSL) and surface roughness (Sa) $( \pm \mathrm{SD})$ of enamel specimen groups after pediatric liquid medicine plus soft drink erosion challenge

\begin{tabular}{lll}
\hline \multirow{2}{*}{ Groups } & \multicolumn{2}{l}{ 3D non-contact profilometry results } \\
\cline { 2 - 3 } & \multicolumn{1}{l}{ TSL } & Sa \\
\hline G4 (NaF varnish) & $31.12 \pm 4.73 \mathrm{a}$ & $0.58 \pm 0.49 \mathrm{a}$ \\
G5 (CPP-ACP varnish) & $27.69 \pm 7.26 \mathrm{a}$ & $0.57 \pm 0.24 \mathrm{a}$ \\
G6 (DD water) & $44.17 \pm 8.55 \mathrm{~b}$ & $1.69 \pm 0.32 \mathrm{~b}$ \\
\hline
\end{tabular}

Means followed by distinct letters are statistically different $(\mathrm{p}<0.05)$. 
and exposed enamel surface besides the increased surface roughness. The present study provides additional data to our previous study (17), which evaluated the effect of $\mathrm{NaF}$ and $\mathrm{CPP}-\mathrm{ACP} / \mathrm{NaF}$ varnishes to inhibit tooth structure loss and alterations in surface roughness after consumption of soft drinks and after pediatric liquid medicine plus soft drink erosion. Based on those previous results (17), Claritin ${ }^{\circledR}$ was chosen to simulate the erosive effects of acid drug
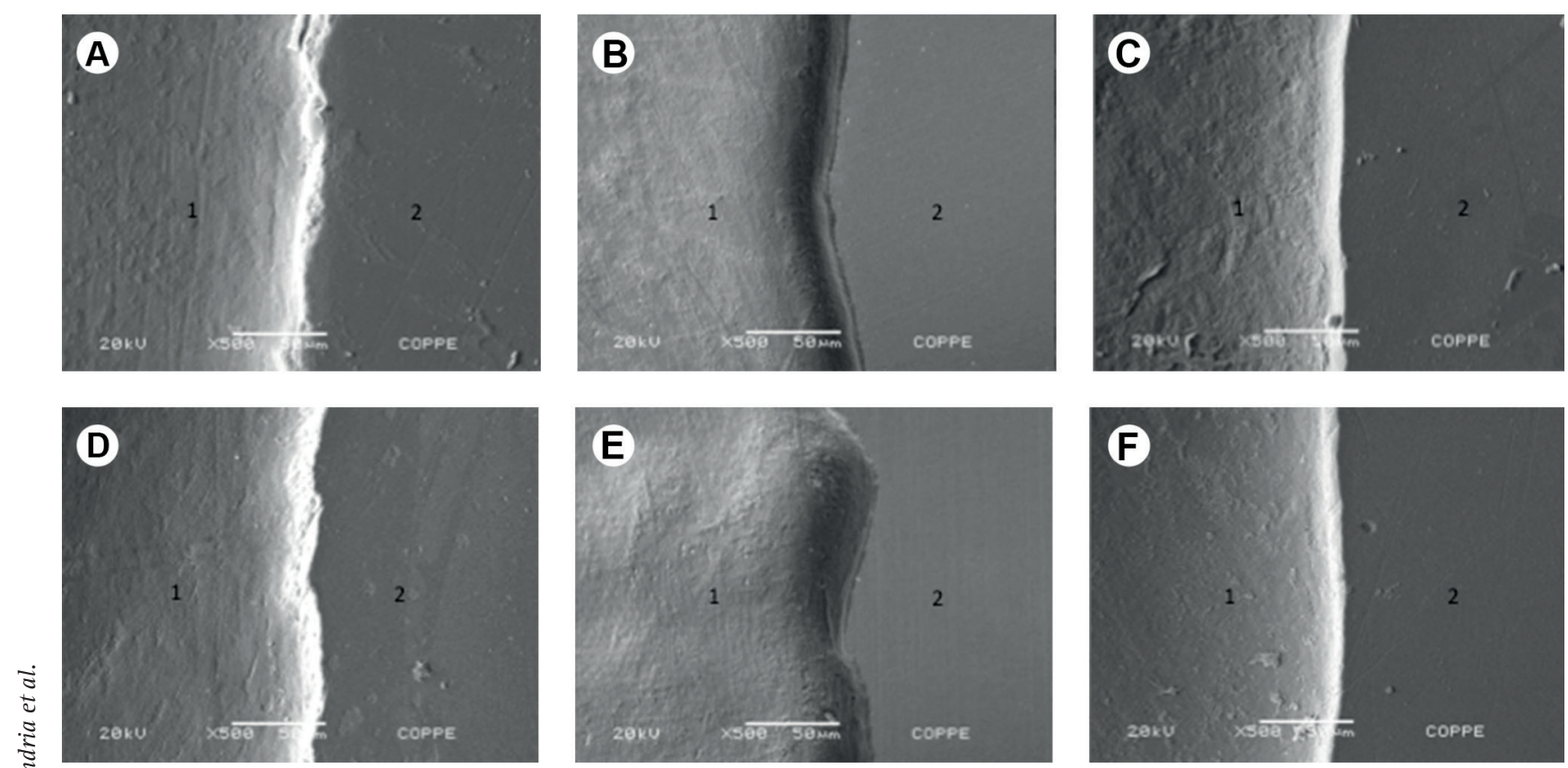

Figure 3. SEM micrographs of enamel surface samples after treatment and erosion challenges at $\square 500$. A-C images = soft drink erosion challenge, D-F images= pediatric liquid medicine + soft drink erosion challenge. (A) and (D) G1 and G4= NaF varnish, (B) and (E) G2 and G5= CPP-ACP/NaF varnish, (C) and (F) G3 and G6= DD water (negative control). 1= exposed area (after erosion), $2=$ unexposed area (sound enamel).
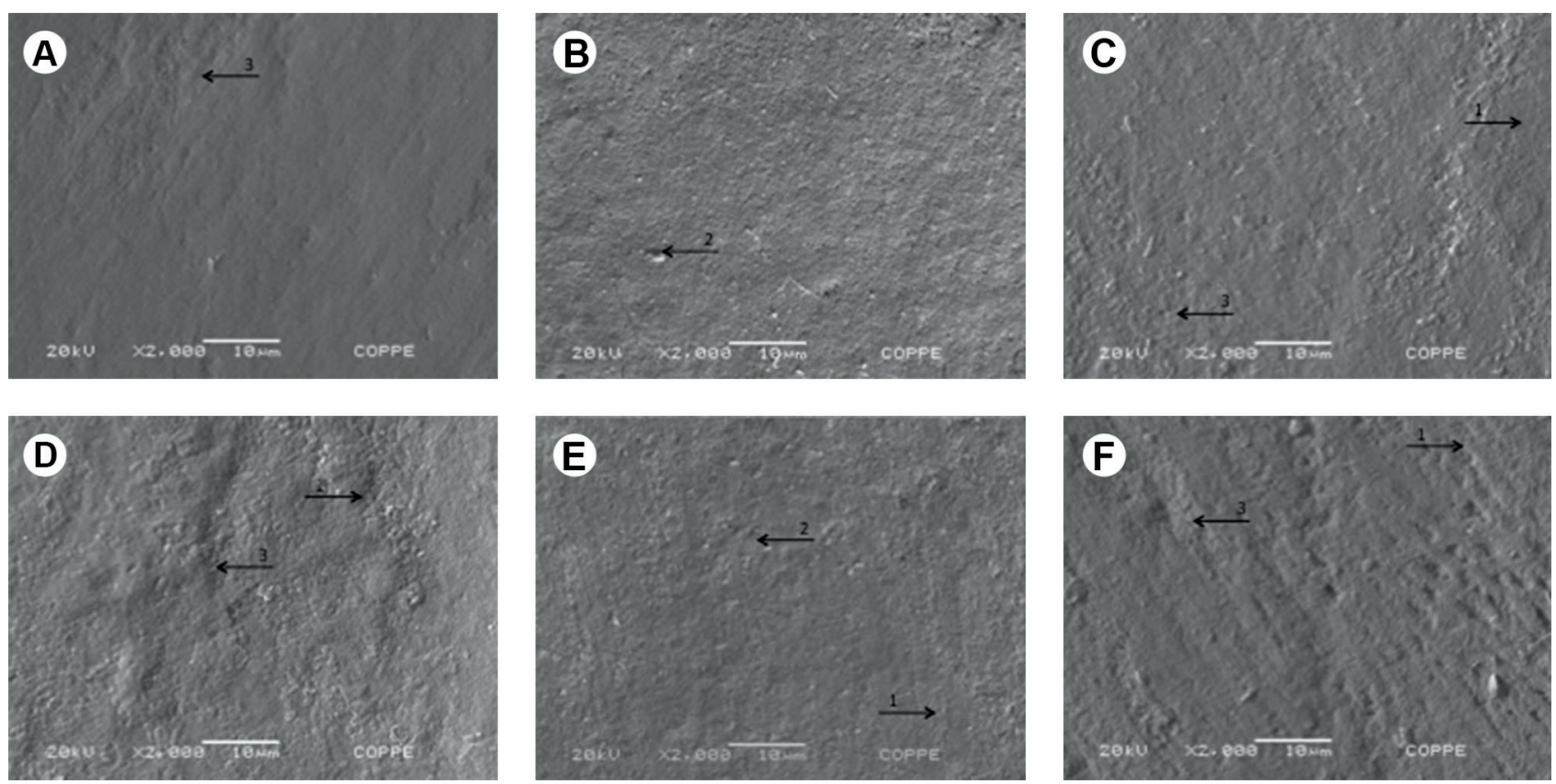

Figure 4. SEM micrographs of enamel surface samples after treatment and erosion challenges at $\square 2000$. A-C images = soft drink erosion challenge, D-F images= pediatric liquid medicine + soft drink erosion challenge. (A) and (D) G1 and G4= NaF varnish, (B) and (E) G2 and G5= CPP-ACP/ $\mathrm{NaF}$ varnish, (C) and (F) G3 and G6= DD water (negative control). Arrow 1= exposure of enamel prisms, arrow 2= small depressions on enamel surface, arrow $3=$ larger depressions/craters. 
caused by pediatric liquid medicine in erosive challenge of this study. Other in vitro studies have also demonstrated that Claritin ${ }^{\circledR}$ may reduce enamel hardness (18-20) and increase surface roughness (17).

In the present study, the varnishes were applied once and removed after $6 \mathrm{~h}$ of application to simulate the clinical condition, since the emphasis was allowing the chemical effect of the varnish components, rather than the mechanical protection. Because of their common clinical use, high fluoride amount and slow components release, varnishes could be an ideal product to be used as a preventive product against dental erosion (21).

As previously proposed by Sales-Peres et al. (16), a severe erosive challenge (6 SDE/day) was undertaken in the present study to verify the potential of the treatments under an extreme condition. This protocol was able to provide fast enamel demineralization as well as to simulate a high erosive risk situation, as seen in the present study. Tests using models that mimic oral conditions are required in the studies, so the sample was immersed in a pediatric liquid medicine for 5 min according to our previous study (17), to simulate the period in which the syrup remains in the oral cavity until its complete ingestion and dilution by the saliva.

The outcomes present study revealed that application of topical CPP-ACP/NaF varnish was effective to decrease tooth structure loss after soft drink erosion. Furthermore, both varnishes reduced tooth structure loss and enamel roughness after pediatric liquid medicine plus soft drink erosion. This is an important result because many children use for long periods antihistaminic medicines such as Claritin ${ }^{\circledR}$ and use of these varnishes could be a good alternative to protect against tooth structure loss and roughness alteration in enamel.

The literature explains the positive results of fluoride varnishes by the formation of a protective barrier of CaF2-like layer on dental tissue that inhibits the contact of acid with enamel and also help the de-remineralization process $(22,23)$.

The NaF varnish demonstrated capacity to inhibit TSL only after PLM/SDE challenge. It may be speculated that this result may be combined to the erosive protocol. After a great erosive challenge, the protective effect of $\mathrm{NaF}$ varnish became more evident.

$\mathrm{CPP}-\mathrm{ACP} / \mathrm{NaF}$ varnish reduced tooth structure loss and enamel roughness alterations after both erosive challenges, probably because calcium and phosphate ions available in CPP-ACP/NaF varnish penetrate in enamel causing ion oversaturation (24). In addition to CaF2 action, the ACP group from CPP-ACP bonds with $\mathrm{F}$ - from $\mathrm{NaF}$ to produce the ACFP phase, which is unstable and rapidly transforms into fluorhydroxyapatite (25).
Also, the casein in this varnish could modify certain enamel mechanical properties, making it less susceptible to mineral loss and reducing the erosive process (25). Other previous studies $(26,27)$ also observed that CPP-ACP/NaF toothpaste showed the best potential to control dental erosion demonstrating the synergy between CPP-ACP and fluoride.

In the 3D topographical and SEM images, the groups treated with $\mathrm{CPP}-\mathrm{ACP} / \mathrm{NaF}$ varnish had the least enamel topography alterations, probably due high bioavailability of calcium contributes to protect enamel surface, making it less irregular even under erosive challenges.

Despite its advantages, such as providing investigation in a controlled environment with a single-variable, this in vitro protocol has limitations, particularly related to its inability to adequately simulate the complex biological dental erosion processes, due the difficulty for matching the solid/solution ratios that occur in vivo. Nevertheless, this study is the first to evaluate the changes in surface enamel topography relative to surface roughness profile and tooth structure loss after erosive challenge from acidic pediatric liquid medicines.

Topical application of CPP-ACP/NaF varnish was effective in improving protection against tooth structure loss after soft drink erosive challenge, and both varnishes were able to reduce tooth structure loss and enamel roughness alteration after pediatric liquid medicine plus soft drink erosive challenge. These findings provided a basis for future in situ studies and clinical trials that can evaluate the effect of these varnishes in clinical erosive tooth wear, especially in cases of patients who use acidic pediatric liquid medicines.

\section{Resumo}

0 presente estudo avaliou o efeito dos vernizes de NaF e CPP-ACP/ $\mathrm{NaF}$ na redução da erosão promovida por refrigerante e associada a um medicamento liquido pediátrico. Os espécimes de esmalte foram prétratados com verniz fluoretado, de acordo com o grupo de alocação: verniz NaF (Duraphat ${ }^{\circledR}$ ) ou verniz CPP-ACP NaF (verniz MI ${ }^{\mathrm{TM}}$ ). Dois tipos distintos de desafio erosivo foram realizados: erosão com refrigerante (ER) ou erosão com medicamento líquido pediátrico e refrigerante (MLP/ER). Espécies de esmalte bovino foram aleatorizados em seis grupos $(n=10): G 1$ $=\mathrm{NaF}+\mathrm{ER} ; \mathrm{G} 2=\mathrm{CPP}-\mathrm{ACP} / \mathrm{NaF}+\mathrm{ER} ; \mathrm{G} 3=$ Água destilada e deionizada $(\mathrm{DD})+\mathrm{ER} ; \mathrm{G} 4=\mathrm{NaF}+\mathrm{MLP} / \mathrm{ER} ; \mathrm{G} 5=\mathrm{CPP}-\mathrm{ACP} / \mathrm{NaF}+\mathrm{MLP} / \mathrm{ER}$ e $\mathrm{G} 6=$ $\mathrm{DD}$ água $+\mathrm{MLP} / \mathrm{ER}$. Antes dos tratamentos, a superficie das amostras foi dividida em duas áreas (não exposta-NE e área exposta-AE). Os espécimes foram avaliados pela técnica de perfilometria $3 \mathrm{D}$ de não-contato para determinar a perda de estrutura dentária (PED) e a rugosidade superficial (RS). A microscopia eletrônica de varredura (MEV) também foi utilizada. Após ER, G2 apresentou os menores valores de PED comparado ao G3 $(p=0,008) . G 1$ e $G 2$ não diferiram entre si $(p=0,203)$ e não houve diferença entre os grupos no que diz respeito a RS. Os resultados de PED e RS para a MLP/ER mostraram que $\mathrm{G} 4$ e $\mathrm{G} 5$ diferiram de $\mathrm{G} 6(\mathrm{p}=0,0001)$, mas não diferiram entre si $(p=1,00)$. Examinando as imagens 3D da perfilometria e de MEV, as maiores diferenças entre UA e EA foram observadas para G3 e G6. 0 verniz CPP-ACP/NaF parece ser um tratamento promissor para reduzir a perda de esmalte por erosão produzida por refrigerante 
e ambos os vernizes mostraram capacidade em reduzir a PED e RS após erosão com medicamento líquido pediátrico associado a refrigerante.

\section{Acknowledgements}

The authors acknowledge the financial support from the CAPES, FAPERJ (E-26/201.316/2014) and CNPq (303535/2016-4 and 152231/2016-1). This study composes the doctorate thesis of the first author.

\section{References}

1. Lussi A, Carvalho TS. Erosive tooth wear: a multifactorial condition of growing concern and increasing knowledge. Monogr Oral Sci 2014;25:1-15.

2. Shellis RP, Barbour ME, Jesani A, Lussi A. Effects of buffering properties and undissociated acid concentration on dissolution of dental enamel in relation to pH and acid type. Caries Res 2013;47:601-611.

3. Salas MM, Nascimento GG, Vargas-Ferreira F, Tarquinio $S B$, Huysmans $\mathrm{MC}$, Demarco FF. Diet influenced tooth erosion prevalence in children and adolescents: Results of a meta-analysis and meta-regression. J Dent 2015;43:865-875.

4. Shellis RP, Featherstone JD, Lussi A. Understanding the chemistry of dental erosion. Monogr Oral Sci 2014;25:163-179.

5. Hellwig E, Lussi A. Oral hygiene products and acidic medicines. Monogr Oral Sci 2013;20:112-118.

6. Neves BG, Farah A, Lucas E, de Sousa VP, Maia LC. Are paediatric medicines risk factors for dental caries and dental erosion? Community Dent Health 2008;27:46-51.

7. Maguire A, Baqir W, Nunn JH. Are sugars-free medicines more erosive than sugars-containing medicines? An in vitro study of paediatric medicines with prolonged oral clearance used regularly and long-term by children. Int J Paediatr Dent 2007;17:231-238.

8. Lussi A, Carvalho TS. The future of fluorides and other protective agents in erosion prevention. Caries Res 2015;49Suppl 1:18-29.

9. Sar Sancakli H, Austin RS, Al-Saqabi F, Moazzez R, Bartlett D. The influence of varnish and high fluoride on erosion and abrasion in a laboratory investigation. Aust Dent J 2015;60:38-42.

10. Cochrane NJ, Shen P, Yuan Y, Reynolds EC. Ion release from calcium and fluoride containing dental varnishes. Aust Dent J 2014;59:100-105.

11. Cochrane NJ, Reynolds EC. Calcium phosphopeptides - mechanisms of action and evidence for clinical efficacy. Adv Dent Res 2012;24:41-47.

12. Nassur C, Alexandria AK, Pomarico L, de Sousa VP, Cabral LM, Maia LC. Characterization of a new TiF(4) and beta-cyclodextrin inclusion complex and its in vitro evaluation on inhibiting enamel demineralization. Arch Oral Biol 2013;58:239-247.

13. Alexandria AK, Vieira TI, Pithon MM, da Silva Fidalgo TK, Fonseca-
Goncalves A, Valenca AM, et al.. In vitro enamel erosion and abrasioninhibiting effect of different fluoride varnishes. Arch Oral Biol 2017;77:39-43.

14. Pithon MM, Dos Santos MJ, Andrade CS, Leao Filho JC, Braz AK, de Araujo RE, et al.. Effectiveness of varnish with CPP-ACP in prevention of caries lesions around orthodontic brackets: an OCT evaluation. Eur J Orthod 2015;37:177-182.

15. Fernandez CE, Tenuta LM, Zarate $P$, Cury JA. Insoluble NaF in Duraphat $(R)$ may prolong fluoride reactivity of varnish retained on dental surfaces. Braz Dent J 2014;25:160-164.

16. Sales-Peres A de C, Marsicano JA, Garcia RP, Forim MR, Silva MF, SalesPeres SH. Effect of natural gel product on bovine dentin erosion in vitro. J Appl Oral Sci 2013;21:597-600.

17. Alexandria AK, Meckelburg $N$ de $A$, Puetter UT, Salles JT, Souza IP, Maia LC. Do pediatric medicines induce topographic changes in dental enamel? Braz Oral Res 2016;30.

18. Costa CC, Almeida IC, Costa Filho LC. Erosive effect of an antihistaminecontaining syrup on primary enamel and its reduction by fluoride dentifrice. Int J Paediatr Dent 2006;16:174-180.

19. Soares DN, Valinoti AC, Pierro VS, Antonio AG, Maia LC. Cross-sectional microhardness of bovine enamel subjected to three paediatric liquid oral medicines: an in vitro study. Eur Arch Paediatr Dent 2012;13:261265.

20. Valinoti AC, Pierro VS, Da Silva EM, Maia LC. In vitro alterations in dental enamel exposed to acidic medicines. Int J Paediatr Dent $2011 ; 21: 141-150$.

21. Lippert F. Fluoride release from fluoride varnishes under acidic conditions. J Clin Pediatr Dent 2014;39:35-39.

22. Ganss C, Lussi A, Schlueter N. The histological features and physical properties of eroded dental hard tissues. Monogr Oral Sci 2014;25:99107.

23. Huysmans $M C$, Young $A$, Ganss $C$. The role of fluoride in erosion therapy. Monogr Oral Sci 2014;25:230-243.

24. Wang $C P$, Huang SB, Liu Y, Li JY, Yu HY. The CPP-ACP relieved enamel erosion from a carbonated soft beverage: an in vitro AFM and XRD study. Arch Oral Biol 2014;59:277-282.

25. Reynolds EC. Calcium phosphate-based remineralization systems: scientific evidence? Aust Dent J 2008;53:268-273.

26. Rallan M, Chaudhary S, Goswami M, Sinha A, Arora R, Kishor A. Effect of various remineralising agents on human eroded enamel of primary teeth. Eur Arch Paediatr Dent 2013;14:313-318.

27. Poggio C, Lombardini M, Dagna A, Chiesa M, Bianchi S. Protective effect on enamel demineralization of a CPP-ACP paste: an AFM in vitro study. J Dent 2009;37:949-954. 